\title{
ASSESSING THE POTENTIAL IMPACT OF THE PROPOSED HAGUE JURISDICTION AND JUDGMENTS CONVENTION ON HUMAN RIGHTS LITIGATION IN THE UNITED STATES
}

\author{
THOMAS E. VANDERBLOEMEN
}

\section{INTRODUCTION}

On September 25, 2000, a Manhattan jury in federal court ordered former Bosnian Serb wartime leader Radovan Karadzic to pay $\$ 4.5$ billion in damages to victims of war crimes committed in the early 1990s war in the former Yugoslavia. ${ }^{1}$ A few weeks earlier, another New York jury rendered a judgment against Karadzic for $\$ 745$ million in a lawsuit focusing on crimes against women in the war. ${ }^{2}$ Despite the seriousness of the cases and the size of the judgments, the plaintiffs may never collect even a portion of the judgments because of the difficulty of enforcement in foreign countries, where Karadzic is more likely to have his assets. While one of the plaintiffs explained that the verdict was less about money and more about exposing the atrocities of the war, other similar judgments have been only symbolic gestures as well, because plaintiffs were unable to collect. ${ }^{3}$

One of the impediments preventing the Karadzic plaintiffs from collecting is the probability that many foreign countries where Karadzic might have assets would refuse to recognize or enforce the judgments. ${ }^{4}$ While the Full Faith and Credit Clause of the United States Constitution requires that judgments rendered in one state be

1. See David Rohde, Jury in New York Orders Bosnian Serb to Pay Billions, N.Y. TIMES, Sept. 26, 2000, at A10.

2. See id.

3. See id.

4. See, e.g., Edward A. Amley, Note, Sue and Be Recognized: Collecting \$ 1350 Judgments Abroad, 107 YALE L.J. 2177, 2178 (1998) (discussing the procedural hurdles in bringing a section 1350 claim and the difficulty in collecting on such a judgment if liability is found). 
enforceable in any other state of the Union, ${ }^{5}$ the United States is party to no international agreement with a similar provision allowing the automatic enforcement and recognition of judgments in foreign courts. $^{6}$

The Hague Conference on Private International Law is drafting a convention that could change the outlook of future judgments similar to those in the Karadzic cases. The proposed Hague Convention on International Jurisdiction and Foreign Judgments in Civil and Commercial Matters ${ }^{7}$ ("proposed convention") would allow the same kind of automatic recognition and enforcement of judgments in courts of different countries that the Full Faith and Credit Clause allows among the United States. The proposed convention has a number of goals, including increasing the certainty and reliability with which civil and commercial judgments will be recognized and enforced around the world. ${ }^{8}$ As a result, it could dramatically enhance the effectiveness of judgments by making them enforceable in all of the countries who sign on.

The proposed convention, however, might be drafted in a way to hinder cases like those against Karadzic. The cases against Karadzic were based on the Alien Tort Claims Act ${ }^{9}$ (ATCA), a law as old as the United States Constitution itself and the subject of much debate, and the more recent Torture Victim Protection $\mathrm{Act}^{10}$ (TVPA). The

5. See U.S. ConST. art. IV, § 1, cl. 1 ("Full Faith and Credit shall be given in each State to the public Acts, Records, and judicial Proceedings of every other State.”).

6. See Maryellen Fullerton, Enforcing Judgments Abroad: The Global ChallengeIntroduction, 24 BROOK. J. INT'L L. 1, 2 (1998) ("The United States, in contrast, is not a party to any international agreement governing the recognition and enforcement of judgments.").

7. The convention is currently in preliminary draft form, as adopted by the Special Commission on October 30, 1999 [hereinafter Proposed Convention]. This draft may be found in American Law Institute, Preliminary Draft Convention on Jurisdiction and Foreign Judgments in Civil and Commercial Matters (Oct. 20, 1999), Hague Conference on Private International Law, available at http://www.hcch.net/e/conventions/draft36e.html (on file with the Duke Law Journal) [hereinafter ALI Report].

8. See infra notes 76-79. Many believe that "the United States gives greater recognition and enforcement to foreign judgments than foreign countries give to U.S. judgments, [explaining in part why] the U.S. has something to gain from [such] a convention." Michael Traynor, An Introductory Framework for Analyzing the Proposed Hague Convention on Jurisdiction and Foreign Judgments in Civil and Commercial Matters: U.S. and European Perspectives, 6 ANN. SURV. INT'L \& COMP. L. 1, 6 (2000). For other recent commentary on the progress of the proposed convention, see generally Edward C.Y. Lau, Update on the Hague Convention on the Recognition and Enforcement of Foreign Judgments, 6 ANN. SURV. INT'L \& COMP. L. 13 (2000).

9. 28 U.S.C. $\$ 1350$ (1994).

10. Id. 
proposed convention may hinder the ability of plaintiffs to use the ATCA and the TVPA at all.

The proposed convention's potential negative effect on ATCA and TVPA litigation stems from its prohibition of certain "exorbitant grounds" of jurisdiction often used by plaintiffs in these cases, namely transient or "tag" jurisdiction. Transient or "tag" jurisdiction is personal jurisdiction based solely on the physical presence of the defendant in the territory, even if the presence is wholly unrelated to the litigation in question. ${ }^{11}$ Because alleged human rights violators often have no other contacts with the United States to maintain jurisdiction, human rights litigants often rely upon tag jurisdiction in the event the defendant happens to be physically present in the territory. ${ }^{12}$ Prohibiting tag jurisdiction, therefore, might effectively curtail ATCA and TVPA cases.

The current version of the proposed convention does contain an exception protecting potential cases involving allegations of human rights violations. ${ }^{13}$ Thus, the proposed convention, depending on how it is interpreted, has the potential to have no effect on or to enhance ATCA and TVPA cases. Even in its current form, however, the proposed convention could negatively impact ATCA and TVPA litigation. Moreover, the proposed convention is still being negotiated, and a final draft could accept, reject, or modify the prohibition on tag jurisdiction and the exception for human rights cases.

Without commenting on the appropriateness of ATCA and TVPA cases in the courts in the United States, Part I of this Note will describe how the ATCA and TVPA operate and the problems litigants face in enforcing their judgments. Part II will explain the structure of the current draft of the proposed convention, and Part III will analyze how the final draft of the proposed convention might hinder, have no effect on, or advance ATCA and TVPA litigation in the United States.

11. See infra notes 60-62 and accompanying text. Forms of "exorbitant" jurisdiction used in other countries, which could be useful to human rights litigants, might also be affected by the proposed convention, such as the mere presence of the defendant's property in the jurisdiction, however unrelated to the litigation, or the nationality of the plaintiff. See infra note 120 and accompanying text.

12. See infra note 60 (discussing the service of process on Radovan Karadzic when he was present in New York on invitation from the United Nations).

13. See infra note 101 and accompanying text. 


\section{The Alien Tort Claims Act AND the TORTURE Victim PROTECTION ACT}

\section{A. Use of the Acts in the Human Rights Context}

The United States affords certain domestic rights of action for persons claiming to be victims of human rights abuses, regardless of where they occur. The Alien Tort Claims Act (ATCA) provides that "district courts shall have original jurisdiction of any civil action by an alien for a tort only, committed in violation of the law of nations or a treaty of the United States." ${ }^{14}$ The Torture Victim Protection Act (TVPA), recently passed by Congress, provides that "[a]n individual who, under actual or apparent authority, or color of law, of any foreign nation... subjects an individual to torture shall, in a civil action, be liable for damages to that individual." ${ }^{15}$

The ATCA, which traces its origins to the first Judiciary Act of 1789 but lay virtually unused for 200 years, has found new life as a means for aliens to sue in U.S. federal courts for damages from alleged human rights violations occurring around the world. ${ }^{16}$ The ATCA was enacted along with the Judiciary Act of 1789 in part to allow a forum in the United States for bringing pirates of the high seas to justice. ${ }^{17}$ Others have viewed the legislative intent behind the ATCA as being rooted in "what the Founders understood to be the nation's duty to propagate and enforce those international law rules that directly regulated individual conduct." ${ }^{18}$ In 1975, Judge Henry

\footnotetext{
14. 28 U.S.C. $\$ 1350$.

15. Id. $\S 1350(2)(\mathrm{a})(1)$.

16. See Anne-Marie Burley, The Alien Tort Statute and the Judiciary Act of 1789: A Badge of Honor, 83 AM. J. INT'L L. 461, 461-62 (1989).

17. See Tel-Oren v. Libyan Arab Republic, 726 F.2d 774, 814 n.23 (D.C. Cir. 1984) (Bork,
} J., concurring). Another view on the legislative intent behind the ATCA is that of national security: there was concern that refusing access to the courts to aliens could provoke international hostility. See id. at 783-84 (Edwards, J., concurring) (quoting Alexander Hamilton's belief that "the federal judiciary ought to have cognizance of all causes in which the citizens of other countries are concerned," for "[t]his is not less essential to the preservation of the public faith, than to the security of the public tranquillity"). But see id. at 816, 821 (Bork, J., concurring) (expressing the view that concerns over national security warrant against hearing ATCA cases). As the opinions in Tel-Oren demonstrate, there is no real consensus as to what Congress meant to do in enacting the "legal Lohengrin." See Jeffrey Rabkin, Note, Universal Justice: The Role of Federal Courts in International Civil Litigation, 95 COLUM. L. REv. 2120, 2125-26 (1995) (discussing national security and other views on the legislative intent of the ATCA).

18. Burley, supra note 16, at 475 (emphasis omitted); see also Rabkin, supra note 17, at 2126 (explaining Professor Burley's observation on the ATCA's legislative intent). 
Friendly discussed the ATCA and remarked that "[t]his old but little used section is a kind of legal Lohengrin; although it has been with us since the first Judiciary Act... no one seems to know whence it came." $" 19$

Regardless of the debate about the origins of Judge Friendly's "legal Lohengrin," ${ }^{20}$ plaintiffs have recently relied upon the ATCA as a means of remedying violations of human rights around the world. ${ }^{21}$ For example, in Filartiga v. Pena-Irala, ${ }^{22}$ a Paraguayan citizen sued the Inspector General of Police of Asuncion for kidnapping and torturing to death his son, Joelito Filartiga. ${ }^{23}$ The United States Court of Appeals for the Second Circuit upheld the jurisdiction of the United States District Court for the Eastern District of New York under the ATCA, even though both the plaintiff and the defendant were Paraguayan and all of the relevant actions took place in Paraguay. ${ }^{24}$ "“[I]nternational law confers fundamental rights upon all people vis-avis their own governments,' including the right to be free from torture." ${ }^{25}$ In holding that a United States court could hear claims

19. IIT v. Vencap, Ltd., 519 F.2d 1001, 1015 (2d Cir. 1975) (citation omitted). Initially, Judge Friendly's observation did little to clarify the ATCA for the author; the most I knew about Lohengrin was that a march from the opera of the same name had been popularized as the "Here Comes the Bride" song (though, incidentally, many Christian organists refuse to play it, on account of its "pagan" origin). As it turns out, Lohengrin was a mythical figure from German lore, a "knight in shining armor" who saved Elsa, a damsel in distress, by defeating the evil Telramund at Antwerp. Lohengrin asked Elsa to marry him, but on the sole condition that she never ask his name or his origin. Elsa popped the forbidden question and inquired into Lohengrin's roots, whereupon he upheld his end of the bargain and bid her farewell. A synopsis of the opera by Wagner is available on the web page of the San Francisco Opera, A Look Back: 1996-1997-Synopsis, at http://www.slote-company.com/sfopera/lookback2/html/lohengrin.htm (last visited Oct. 7, 2000) (on file with the Duke Law Journal).

20. Vencap, 519 F.2d at 1015; see also M. O. Chibundu, Making Customary International Law Through Municipal Adjudication: A Structural Inquiry, 39 VA. J. INT'L L. 1069, 1096 (1999) (agreeing that Judge Friendly's observation remains as true today as when he wrote it).

21. For an extensive list of ATCA cases against nonstate defendants, see Deborah L. Zimic, Foreign Sovereign Immunity-Exceptions to Foreign Sovereign Immunity-The Foreign Sovereign Immunities Act Does Not Prohibit Invocation of the Alien Tort Claims Act to Exercise Federal Court Jurisdiction over a Foreign Nation's Non-Commercial Tort in Violation of International Law, 28 VA. J. INT'L L. 221, 223 n.9 (1987). Ironically, one of the few instances before 1980 in which the ATCA (actually, a predecessor to it) was successfully invoked as a ground of jurisdiction was in Bolchos v. Darrell, 3 F. Cas. 810 (D.S.C. 1795) (No. 1607), in which a French citizen sought restitution for slaves taken from a Spanish ship seized at war. The earlier use of the ATCA to protect a slaveholder's "property" is ironic given the statute's current use to protect human rights.

22. 630 F.2d 876 (2d Cir. 1980).

23. See id. at 878 .

24. See id. at 887.

25. Sung Teak Kim, Note, Adjudicating Violations of International Law: Defining the Scope 
regarding torts that violated international law, regardless of where they occurred, the district court relied upon the doctrine of transitory torts, which provides that "liability for certain tortious acts follow[s] the tortfeasor, such that he could be subject to suit for th[ose] act[s] in any forum." ${ }^{26}$

The TVPA apparently endorsed Filartiga's approach to the ATCA. ${ }^{27}$ The TVPA was enacted in 1992, and its legislative history indicates its drafters' intent to address official, governmentsanctioned torture or extrajudicial killing. ${ }^{28}$ The TVPA is inherently linked to the ATCA, and by no means was intended to replace it. ${ }^{29}$ Unlike the ATCA, the TVPA is not a jurisdictional statute. Thus, a TVPA plaintiff must establish its jurisdiction via the ATCA, or through some other means such as the general federal question jurisdiction from section $1331 .^{30}$

of Jurisdiction Under the Alien Tort Statute-Trajano v. Marcos, 27 CORNELL INT’L L.J. 387, 392 (1994) (quoting Filartiga, 630 F.2d at 885).

26. Id. The doctrine of transitory torts holds that a person may be liable in courts of any country for an act wherever it is committed. See William S. Dodge, The Historical Origins of the Alien Tort Statute: A Response to the "Originalists," 19 Hastings InT'L \& COMP. L. REV. 221, 234 n.95 (1996). Apart from the human rights context, it has been applied to other situations as well. See, e.g., Darnell v. Rupplin, 371 S.E.2d 743, 745 (N.C. Ct. App. 1988) (alienation of affections as a transitory tort), cited in Jennifer E. McDougal, Comment, Legislating Morality: The Actions for Alienation of Affections and Criminal Conversation in North Carolina, 33 WAKE FOREST L. REV. 163, 185 n.155 (1998); Peter Nicolas, Comment, The Use of Preclusion Doctrine, Antisuit Injunctions, and Forum Non Conveniens Dismissals in Transnational Intellectual Property Litigation, 40 VA. J. INT'L L. 331, 354 (1999) (patent infringement as a transitory tort).

27. See Senate Comm. on the Judiciary, The Torture Victim Protection Act of 1991, S. ReP. No. 102-249, at 4 [hereinafter Torture Victim Protection ACT] (discussing the ATCA and Filartiga, and explaining that Filartiga "has met with general approval"); see also David P. Kunstle, Note, Kadic v. Karadzic: Do Private Individuals Have Enforceable Rights and Obligations Under the Alien Tort Claims Act?, 6 DUKE J. COMP. \& INT'L L. 319, 343 (1996) ("[A]s indicated by both the language and the legislative history of the TVPA, congressional reaction to Filartiga's interpretation of the ATCA was anything but hostile.").

28. See Kadic v. Karadzic, 70 F.3d 232, 245 (2d Cir. 1995); see also TORTURE VICTIM PROTECTION ACT, supra note 27, at 3 ("The purpose of this legislation is to provide a Federal cause of action against any individual who, under actual or apparent authority or under color of law of any foreign nation, subjects any individual to torture or extrajudicial killing.").

29. See Torture Victim Protection Act, supra note 27, at 3 ("The TVPA would establish an unambiguous basis for a cause of action that has been successfully maintained under an existing law, section 1350 .... Section 1350 has other important uses and should not be replaced.").

30. See Kadic, 70 F.3d at 246. Section 1331 of Title 28 of the United States Code provides that " $[\mathrm{t}]$ he district courts shall have original jurisdiction of all civil actions arising under the Constitution, laws, or treaties of the United States." 28 U.S.C. $§ 1331$ (1994). As a point of historical interest, "complete federal question jurisdiction" did not exist when the ATCA was enacted in 1789 but only came along in 1875. Tel-Oren v. Libyan Arab Republic, 726 F.2d 774, 
Litigants have recently invoked the ATCA and the TVPA to attempt to vindicate human rights abuses abroad, perhaps most notably in the case of Kadic v. Karadzic, ${ }^{31}$ the suit against Radovan Karadzic, wartime leader of the self-proclaimed Bosnian-Serb republic, for various atrocities and brutal acts allegedly committed by the Bosnian-Serb military forces. ${ }^{32}$ In Kadic, a three-judge panel of the U.S. Court of Appeals for the Second Circuit held that the plaintiffs established the necessary federal subject matter jurisdiction under the ATCA and had brought forth allegations that, if proven true, could be remedied by the ATCA and the TVPA: "[The ATCA] appears to provide a remedy for the appellants' allegations of violations related to genocide, war crimes, and official torture, and the Torture Victim Act also appears to provide a remedy for their allegations of official torture, [thus] their causes of action are statutorily authorized." ${ }^{33}$ The cases against Karadzic went back to trial, resulting in over $\$ 5$ billion in judgments being entered against $\operatorname{him}^{34}$

Debate remains over the appropriateness of hearing these types of human rights cases in American courts, especially in cases involving foreign parties and acts that took place in foreign lands seeming to have little connection to the United States. ${ }^{35}$ In the words

784 (D.C. Cir. 1984) (Edwards, J., concurring).

31. 70 F.3d 232, 237 (2d Cir. 1995) (holding that a district court could hear claims of torture committed against Muslim women allegedly committed by Serbian troops); see also Hilao v. Estate of Marcos, 103 F.3d 767 (9th Cir. 1996) (allowing a class action by Philippine nationals against a former Philippine president's estate for violations of human rights); In re Estate of Ferdinand E. Marcos Human Rights Litig., 978 F.2d 493 (9th Cir. 1992) (allowing an action under ATCA by a Philippine citizen against the daughter of the former Philippine president, claiming wrongful death of her Philippine son caused by torture); National Coalition Gov't v. Unocal, Inc., 176 F.R.D. 329 (C.D. Cal. 1997) (denying a motion to dismiss of an oil company sued for violations of ATCA in connection with allegations of forced labor on a pipeline project); Xuncax v. Gramajo, 886 F. Supp. 162 (D. Mass. 1995) (awarding damages under ATCA and TVPA for violations of international law including summary execution or "disappearance," torture, arbitrary detention, and cruel, inhuman and degrading treatment).

32. See Kadic, 70 F.3d at 237.

33. Id. at 246.

34. See Rohde, supra note 1, at A10.

35. See Conversation Between Thomas E. Vanderbloemen and Paul D. Carrington, Harry R. Chadwick, Sr. Professor of Law, Duke University (Aug. 25, 2000) [hereinafter Carrington Conversation]. First, there is a federalism concern that federal courts have no business hearing cases that would otherwise, but for the ATCA, fall within the jurisdiction of the state courts, see $i d$., and that evolving notions of international human rights law should not be a part of federal "law." See Tel-Oren v. Libyan Arab Republic, 776 F.2d 774, 827 (D.C. Cir. 1984) (Robb, J., concurring) ("Courts ought not to serve as debating clubs for professors willing to argue over what is or what is not an accepted violation of the law of nations."). Similarly, the belief also 
of Karadzic himself in a letter to United States District Judge Peter K. Leisure, who presided over the billion dollar case, "Can you really hope to find truth, or do justice, or protect rights of people in distant nations? ... Do you really believe that attaching a U.S. dollar sign to human tragedy around the world by empty judgments in uncontested lawsuits is a step toward peace or justice?" ${ }^{36}$ However, many view these cases as wholly appropriate, as they often serve as the sole means for exposing human rights violators, have significant deterrent effects, and help the healing process of victims. ${ }^{37}$ For example, Judge Leisure stressed that "[i]t's very important that the United States of America rises to the occasion when these things happen, and we not just wait for the United Nations war crimes tribunal." ${ }^{, 38}$

A number of barriers can impede litigants proceeding under the ATCA and the TVPA. For example, the Foreign Sovereign Immunities Act of $1976^{39}$ (FSIA) generally bars jurisdiction over foreign sovereigns in United States courts ${ }^{40}$ and can pose problems for human rights litigants. However, the FSIA has been construed as having exceptions allowing ATCA and TVPA suits against foreign government officials who act beyond the scope of their power, for example, by committing an act such as torture that a government

exists that these cases are a violation of separation of powers, because courts should not infer that international law creates private rights of action. See id. at 801 (Bork, J., concurring). There is a more general concern that these cases simply should not be heard by any American court when they concern acts in foreign lands committed by and against foreigners. See TORTURE Victim Protection ACt, supra note 27, at 14 (minority views of Messrs. Simpson and Grassley) ("[T]he United States is not the appropriate forum for a foreign national to hold a foreign defendant to answer for action which occurred far from the United States.").

36. Rohde, supra note 1, at A10 (internal quotation marks omitted). Karadzic is still at large in Bosnia. He contested the court's jurisdiction over him, but, upon losing on that issue, declined to defend himself. See id.

37. See Torture Victim Protection Act, supra note 27, at 3-4 ("A state that practices torture and summary execution is not one that adheres to the rule of law. Consequently, the Torture Victim Protection Act (TVPA) is designed to respond to this situation by providing a civil cause of action in U.S. courts for torture committed abroad."); see also infra notes 68-69 and accompanying text (discussing the healing and deterrent effects of ATCA and TVPA judgments). But cf. Tel-Oren, 726 F.2d at 826 n.5 (Robb, J., concurring) (discussing how "[a] plaintiff's individual victory, if it entails embarrassing disclosures of this country's approach to the control of the terrorist phenomenon, may in fact be the collective's defeat").

38. Rohde, supra note 1, at A10 (internal quotation marks omitted).

39. Pub. L. No. 94-583, 90 Stat. 2891 (codified at 28 U.S.C. $\S \S 1330,1441(d), 1602-11$ (1994)).

40. See Argentine Republic v. Amerada Hess Shipping Corp., 488 U.S. 428, 431, 443 (1989) (holding that none of the exceptions to the FSIA allowed a court to hear claims against a foreign state for the sinking of a private vessel by the Argentine military during the Falklands War). 
would not publicly endorse. ${ }^{41}$ While the case law is by no means clear cut $^{42}$ the exceptions are allowing victims of alleged human rights abuses their day in American courts. ${ }^{43}$ Other hurdles, such as the Act of State doctrine ${ }^{44}$ and the doctrine of forum non conveniens, ${ }^{45}$ can also prevent ATCA and TVPA litigants from having their cases heard in U.S. courts. ${ }^{46}$

\section{B. Jurisdiction Under the ATCA and the TVPA}

A striking aspect of the ATCA and the TVPA is that they can be used in a U.S. court in a case involving a foreign plaintiff, a foreign defendant, and activity that occurred outside the United States. ${ }^{47}$ In

41. See Kim, supra note 25, at 411. For a more elaborate discussion of how the FSIA and its exceptions operate, especially in relation to ATCA and TVPA suits, see id. at 390 n.27.

42. See Michael Byers, State Immunity and the Violation of Human Rights by Jurgen Brohmer (1997), 92 AM. J. INT'L L. 165, 167 (1998) (book review) (discussing the "complicated, multijurisdictional, multilingual law of state immunity"); Rabkin, supra note 17, at 2136 (attempting to understand the "confusion" and "mess" of the ATCA, TVPA, and FSIA).

43. See Michael Byers, Decisions of British Courts During 1997, 68 BRIT. Y.B. INT'L L. 302, 317 (1997) (reporting on the case of Propend Finance Party Ltd. v. Sing, [1997] T.L.R. 238 (C.A.), and explaining that the FSIA "has been interpreted as not applying to government officials below the level of head of State, or as not applying to officials acting on their own authority rather than on the authority of their State" (citation omitted)).

44. See Banco Nacional de Cuba v. Sabbatino, 376 U.S. 398, 416 (1964) (“" "[T] he courts of one country will not sit in judgment on the acts of the government of another done within its own territory."' (quoting Underhill v. Hernandez, 168 U.S. 250, 252 (1897))).

45. See Piper Aircraft Co. v. Reyno, 454 U.S. 235, 241 (1981) (explaining that a case may be dismissed at the discretion of the trial court on the grounds of forum non conveniens if an alternative forum has jurisdiction to hear the case, and when the chosen location would “"establish ... oppressiveness and vexation to a defendant ... out of all proportion to plaintiff's convenience,' or when the 'chosen forum [is] inappropriate because of considerations affecting the court's own administrative and legal problems" (quoting Koster v. Lumbermens Mut. Cas. Co., 330 U.S. 518, 524 (1947))). Piper suggests, however, that ATCA cases might not be completely in danger. For example, where a remedy in an alternative forum is "so clearly inadequate or unsatisfactory that it is no remedy at all," an unfavorable change in law between the forums would be relevant. Id. at 254 . Similarly, "dismissal would not be appropriate where the alternative forum does not permit litigation of the subject matter of the dispute." Id. at 254 n.22. Keeping in mind the statement from the legislative history of the TVPA that "[a] state that practices torture and summary execution is not one that adheres to the rule of law," TORTURE Victim PROTECTION ACT, supra note 27, at 3, dismissal of an ATCA or TVPA case on forum non conveniens grounds in many instances would not be warranted according to Piper.

46. See Zimic, supra note 21 , at $225 \mathrm{n} .12$ (discussing these and other hurdles). These problems can be of equal concern in other countries. For example, in the United Kingdom, human rights litigants can face similar issues with regard to forum non conveniens. See generally HuMAN RightS COMM., INT'L L. ASS'N (BRITISH BRANCH), DRAFT REPORT ON CIVIL ACTIONS IN THE ENGLish COURT FOR SERIOUS Human Rights Violations ABROAD 30-37 (2000) (on file with Duke Law Journal).

47. See Kadic v. Karadzic, 70 F.3d 232, 236 (2d Cir. 1995) ("Most Americans would 
U.S. courts, it is necessary for plaintiffs to establish that the court has subject matter jurisdiction over the claim, and that it has personal jurisdiction over the defendant. ${ }^{48}$ The methods by which plaintiffs often obtain personal jurisdiction in ATCA and TVPA cases are threatened by the proposed Hague Judgments Convention. Before discussing these methods and how they might be affected by the proposed convention, the subject matter jurisdiction of human rights cases involving foreign acts and foreign parties must be clarified.

To establish subject matter jurisdiction under the ATCA, a plaintiff must demonstrate that "three conditions are satisfied: (1) an alien sues (2) for a tort (3) committed in violation of the law of nations (i.e., international law)." ${ }^{49}$ In fact, the ATCA has been interpreted as granting federal subject matter jurisdiction and creating a cause of action when a plaintiff "can establish that the abuses allegedly inflicted upon her constitute violations of international law." "[T] "The torturer has become-like the pirate and slave trader before him-hostis humani generis, an enemy of all mankind." ${ }^{51}$ As a result, the United States can claim universal subject matter jurisdiction for certain offenses "significant enough to threaten the interests "of civilization everywhere." ${ }^{52}$ The notion of universal

probably be surprised to learn that victims of atrocities committed in Bosnia are suing the leader of the insurgent Bosnian-Serb forces in a United States District Court in Manhattan.").

48. See Ruhrgas AG v. Marathon Oil Co., 526 U.S. 574, 577 (1999) ("Jurisdiction to resolve cases on the merits requires both authority over the category of claim in suit (subject matter jurisdiction) and authority over the parties (personal jurisdiction), so that the court's decision will bind them.").

49. Kadic, 70 F.3d at 238. Here we are talking about federal subject matter jurisdiction. Of course, any state court whose subject matter jurisdiction included torts could entertain similar human rights litigation. In fact, because in many instances the parties are all from foreign states, with no one qualifying as a "citizen" of one of the United States, diversity jurisdiction would not exist to give the federal court jurisdiction. See 28 U.S.C. § 1332 (1994) (laying out the elements of federal diversity jurisdiction). Thus, to get into federal court, the plaintiff would have to establish federal subject matter jurisdiction under the ATCA or under the general federal question jurisdiction. See id. $\S 1331$ (detailing the elements of federal subject matter jurisdiction).

50. Xuncax v. Gramajo, 886 F. Supp. 162, 179 (D. Mass. 1995); see also Tel-Oren v. Libyan Arab Republic, 726 F.2d 774, 776-81 (D.C. Cir. 1984) (Edwards, J., concurring) (articulating the belief that federal courts have jurisdiction in cases involving rights recognized by international law). But cf. Kim, supra note 25, at 406 (approving of a court determination that the ATCA " is simply a jurisdictional statute and creates no cause of action itself" (quoting Trajano v. Marcos, 978 F.2d 493, 503 (9th Cir. 1992))).

51. Filartiga v. Pena-Irala, 630 F.2d 876, 890 (2d Cir. 1980).

52. Kim, supra note 25, at 416 (quoting Jeffrey M. Blum \& Ralph G. Steinhardt, Federal Jurisdiction over International Human Rights Claims: The Alien Tort Claims Act After Filartiga v. Pena-Irala, 22 HARV. INT’L L.J. 53, 60 (1981)). 
jurisdiction is based on the principle that states can claim jurisdiction "to define and punish certain offenses recognized by the community of nations as of universal concern,' . . . even where no other recognized basis of jurisdiction is present., ${ }^{, 53}$

The use of this type of universal jurisdiction over violations of human rights is not restricted to the United States. ${ }^{54}$ Many other countries have created criminal penalties for human rights violators and war criminals on the basis of treaty obligations, such as the 1948 Genocide Convention. ${ }^{55}$ Belgium, Denmark, France, Germany, Israel, Spain, and Switzerland, for example, have done their part domestically to prosecute non-nationals for war crimes and violations of human rights. ${ }^{56}$ One needs only to look at the current case against former Chilean head of state Augusto Pinochet to note the worldwide use of universal jurisdiction. ${ }^{57}$ While many of these examples of universal jurisdiction apply to criminal prosecutions, other countries have applied these principles in civil cases in the same spirit as the ATCA and the TVPA. ${ }^{58}$

Plaintiffs must establish a court's subject matter jurisdiction and personal jurisdiction. In other words, the court must not only be able to hear the type of claim presented, but the defendant must have a sufficient relationship with the jurisdiction for the court to proceed..$^{59}$

53. Tel-Oren, 726 F.2d at 781 n.7 (Edwards, J., concurring) (quoting RESTATEMENT OF THE LAW OF ForEIGN RELATIONS (REVISED) $§ 404$ (Tentative Draft No. 2, 1981) (citations omitted)).

54. See Paul R. Dubinsky, Hague Conference on Private Int'l Law Working Document No. 117: Proposals of the Hague Conference and Their Effect on Efforts to Enforce International Human Rights Through Adjudication (Nov. 1998), available at http://law.gov.au/publications/ haguepaper/attachc.html (on file with the Duke Law Journal).

55. See Convention on the Prevention and Punishment of the Crime of Genocide, Dec. 9, 1948, 78 U.N.T.S. 227. Article V of the Genocide Convention "requires contracting states to enact domestic legislation to provide effective penalties for persons guilty of genocide." Dubinsky, supra note 54.

56. See Dubinsky, supra note 54.

57. See Curtis A. Bradley \& Jack L. Goldsmith, Pinochet and International Human Rights Litigation, 97 MICH. L. REV. 2129, 2133-34 (1999).

58. See Dubinsky, supra note 54 (citing the examples of the United Kingdom and Switzerland, and quoting the RESTATEMENT (THIRD) OF THE FOREIGN RELATIONS LAW OF THE UNITED STATES $§ 404 \mathrm{cmt}$. b (1987), which states that "international law does not preclude the application of non-criminal law on [the] basis [of universal interests]"); see also TORTURE Victim PROTECTION ACT, supra note 27, at 4-5 (explaining that "[s]everal states have established that the international law of human rights can be enforced on behalf of individuals in their courts" and giving the examples of Belgium, Germany, and the Philippines, which were mentioned by the United States in its Filartiga amicus brief).

59. See Ruhrgas AG v. Marathon Oil Co., 526 U.S. 574, 587-88 (1999) (discussing the order 
Personal jurisdiction over the defendants in a large number of ATCA and TVPA cases is achieved via transient or "tag" jurisdiction, that is, jurisdiction obtained by serving the defendant while he or she is physically present within the United States. ${ }^{60}$ Many criticize the use of personal jurisdiction based solely on the presence of the defendant in the jurisdiction where the suit is brought. ${ }^{61}$ However, the Supreme Court "has reaffirmed that such 'transient jurisdiction' is permissible, even if the defendant is only in the state briefly or for reasons unrelated to the litigation." ${ }^{\prime 2}$ Because of the belief by many, especially in other countries, that tag jurisdiction is unreasonable and should not be allowed in the framework of the proposed convention, ${ }^{63}$ human rights litigation relying on this and other similar methods may face problems.

In addition to the procedural hurdles of the Act of State doctrine, forum non conveniens, and the FSIA, litigants can also face problems when attempting to tag defendants who are immune from service of process. For example, individuals called into a jurisdiction for the purposes of participating in litigation can be considered immune from tag service, as may heads of state engaged in official business. $^{64}$ In fact, in Kadic, Radovan Karadzic claimed he was immune from service of process as an invitee of the United Nations. ${ }^{65}$ The court of appeals rejected Karadzic's claim of immunity because it appeared he was served outside of the United Nations Headquarters District, because the Agreement Between the United Nations and the

in which a district court should address personal and subject matter jurisdiction).

60. See FED. R. CIV. P. 4(e)(2) (authorizing personal service of process upon an individual physically present in any judicial district of the United States); Kadic v. Karadzic, 70 F.3d 232, 237 (2d Cir. 1995) (involving personal jurisdiction obtained over the defendant by serving him with process while present in Manhattan on an invitation from the United Nations); Filartiga v. Pena-Irala, 630 F.2d 876, 878 (2d Cir. 1980) ("Thus, whenever an alleged torturer is found and served with process by an alien within our borders, $\S 1350$ provides federal jurisdiction.").

61. See Jack H. Friedenthal et Al., Civil Procedure $§ 3.17$ (2d ed. 1993) (explaining that, under Shaffer v. Heitner, 433 U.S. 186 (1977), personal jurisdiction must be consistent with a "minimum contacts" test).

62. Joseph W. Glannon, Civil Procedure: Examples and ExPlanations 15 (3d ed. 1997) (citing Burnham v. Superior Ct., 495 U.S. 604 (1990)).

63. See Kevin M. Clermont, Jurisdictional Salvation and the Hague Treaty, 85 CORNELL L. REV. 89, 111-12 (1999).

64. See Kadic, 70 F.3d at 248 (citing 4 Charles A. Wright \& ARThur R. Miller, FEDERAL PRACTICE AND PROCEDURE $§ 1076$ (2d ed. 1987)).

65. See Kadic, 70 F.3d at 247. Kadic relied on federal common law and on the provisions of the Agreement Between the United Nations and the United States regarding the Headquarters of the United Nations. See id. at 247-48. 
United States regarding the Headquarters of the United Nations did not grant such an immunity to inivitees, and because he was not a recognized head of state. ${ }^{6}$ Regardless of the decision in Kadic, immunity from service of process could still create complications for ATCA and TVPA litigants.

\section{The Problems of Enforcing ATCA and TVPA Judgments}

While the proposed convention has the potential to hinder human rights litigation, ${ }^{67}$ it also has the prospect of assisting human rights litigants if it would allow for more worldwide recognition of ATCA and TVPA judgments. The process of bringing a case before a neutral judge to explain the abuses one has suffered has been described as a valuable part of a victim's healing process. ${ }^{68}$ Furthermore, significant deterrent effects are created by judgments rendered against defendants for violations of human rights. ${ }^{69}$ In many ways, however, an airing of grievances and deterrence of future violations may be the only realistic relief a plaintiff receives. Due to the high likelihood that the defendants in ATCA and TVPA litigation are foreign, any judgments obtained by plaintiffs are largely symbolic unless they are recognized and enforced in the countries where the defendants maintain assets. ${ }^{70}$ The proposed convention, which would allow automatic enforcement and recognition of certain judgments in the courts of all signatory states, would not only make the psychological effect of having the world hear a victim's case a more effective part of the healing process, but it would greatly enhance the chance that the judgment will be collected. ${ }^{71}$ Near-worldwide

66. See id. at 247-48.

67. This Note intends to discuss the potential impact of the proposed convention on cases proceeding under the ATCA and the TVPA. The term "human rights litigation" therefore refers to actions under the ATCA and the TVPA.

68. See Amley, supra note 4, at 2180.

69. Deterrent effects could be present especially when a government is indirectly implicated through the actions of one of its officials. In the context of the Inter-American Human Rights Court, "[t]he threat of negative publicity is a persuasive force which often compels governments to comply with international human rights norms." Jo M. Pasqualucci, Provisional Measures in the Inter-American Human Rights System: An Innovative Development in International Law, 26 VAND. J. TRANSNAT'L L. 803, 807-08 (1993).

70. See Amley, supra note 4, at 2178 (discussing the need for ATCA judgments to be enforced in foreign courts for potential human rights plaintiffs to have greater belief in the ATCA and the TVPA).

71. See id. at 2208 . 
recognition would also make it difficult for human rights violators to shift assets from jurisdiction to jurisdiction. ${ }^{72}$

Despite the potential benefits of the proposed convention, as the following part will illustrate, the results of the current negotiations at the Hague could severely affect the use of the ATCA and the TVPA by human rights litigants. ${ }^{73}$

\section{The Proposed Hague Judgments Convention}

\section{A. The Purposes and Benefits of the Proposed Convention}

Within the United States, the limits of jurisdiction and the enforcement and recognition of judgments from state to state are dictated by the Due Process Clause ${ }^{74}$ and the Full Faith and Credit Clause $^{75}$ of the Constitution. Outside our borders, however, the United States is currently not a party to any treaty, bilateral or multilateral, governing jurisdiction or the enforcement and recognition of judgments from country to country. ${ }^{76}$ Thus, one may predict with some certainty that a judgment from North Carolina will be enforced in South Carolina or California, but the same judgment may be given no effect at all in Mexico or Germany.

The predictability gained from the Full Faith and Credit Clause is an asset to those who use the courts in the United States, and a Hague Judgments Convention could enhance the reliability and

72. See id. at 2209-10 (commenting that recognition of section 1350 judgments abroad "dovetails with other items on today's human rights agenda").

73. Of course, even if the convention were to be drafted to allow for the maximum enforcement of human rights judgments, it would still be limited to those countries that signed the proposed convention. Having more jurisdictions where a judgment could be enforced is certainly better for human rights litigants, but, given that many traditionally asset-sheltering jurisdictions probably will not sign the proposed convention, the reality of enhanced monetary recovery may still be elusive.

74. See U.S. CONST. amends. V, XIV; see also Ronald A. Brand, Due Process, Jurisdiction and a Hague Judgments Convention, 60 U. PITT. L. REV. 661, 664 (1999) ("No state or federal court may exercise jurisdiction in a manner that would deny a defendant the fundamental rights of due process.").

75. See U.S. CONST. art. IV, $\S 1$, cl. 1 ("Full Faith and Credit shall be given in each State to the public Acts, Records, and judicial Proceedings of every other State.").

76. See Fullerton, supra note 6, at 2 ("The United States, in contrast, is not a party to any international agreement governing the recognition and enforcement of judgments."). On the domestic front, the Uniform Foreign Money-Judgments Recognition Act is a uniform piece of legislation adopted by at least 28 U.S. jurisdictions that allows recognition of foreign moneyjudgments in a manner similar to that of judgments from other states. See Traynor, supra note 8, at 4 . 
predictability of enforcement of decisions from courts around the world. $^{77}$ Reducing the phenomenon of forum-shopping, and preventing discrimination against Americans subjected to "overlybroad assertions of jurisdiction by European countries" have also been cited as advantages of the convention. ${ }^{78}$ The proposed convention may even have the effect of cleaning up the "mess" of U.S. domestic jurisdictional law. ${ }^{79}$

The proposed Hague convention would obligate a contracting state's courts to observe certain rules for jurisdiction in civil and commercial cases involving parties from the other contracting states, and to recognize and enforce civil and commercial judgments rendered by the courts of other contracting states as long as the rendering court had observed the prescribed jurisdictional rules. The current draft of the proposed convention would apply to "action[s] in tort or delict," $" 80$ as well as other civil and commercial matters. Thus,

77. Notably, since many foreign courts refuse to enforce or recognize judgments on the ground that the jurisdiction asserted was too broad, a Hague Convention stating certain bases of jurisdiction which, if found, would automatically require enforcement or recognition, could help litigants going to foreign courts avoid invalidation. See Andrew L. Strauss, Where America Ends and the International Order Begins: Interpreting the Jurisdictional Reach of the U.S. Constitution in Light of a Proposed Hague Convention on Jurisdiction and Satisfaction of Judgments, 61 ALB. L. REV. 1237, 1238 (1998).

78. Id. at 1239; see also Andreas F. Lowenfeld, Editorial Comment, Forum Shopping, Antisuit Injunctions, Negative Declarations, and Related Tools of International Litigation, 91 AM. J. INT'L L. 314, 314 (1997) (discussing forum shopping and the negotiation of the proposed convention).

79. See Clermont, supra note 63, at 89 (1999) ("Ironically, this treaty would ... provid[e] the opportunity to untangle the jurisdictional law applied at home.").

80. Proposed Convention, supra note 7, art. 10. Interestingly, human rights litigants could face difficulty with the current version of Article 10, which states that a "plaintiff may bring an action in tort or delict in the courts of the State" where the act or omission occurred, or where the injury arose. $I d$. The human rights litigant seeking to make use of the ATCA or similar legislation might not be unduly restricted if the tort action "could only be brought" where the act or omission occurred or where the injury arose; psychological injuries can potentially arise long after an act or omission, meaning that the location of the act or omission would not necessarily have to be the location of the injury. However, Article 10 currently provides that "[i]f an action is brought in the courts of a State only on the basis that the injury arose or may occur there, those courts shall have jurisdiction only in respect of the injury that occurred or may occur in that State, unless the injured person has his or her habitual residence in that State." Id. art. 10, § 4. Furthermore, if the plaintiff brings the case in the courts of the state where the injury occurred, it must prove that the defendant could have reasonably foreseen that the injury would arise there. See id. art. 10, $\S 1(\mathrm{~b})$. Obviously, limitations on the forum of tort cases could impact the usefulness of the doctrine of transitory torts in ATCA and TVPA cases. See supra note 26 (outlining the doctrine of transitory torts). For the purposes of the current discussion, however, this Note assumes that tort actions alleging violations of human rights, particularly under the ATCA, the TVPA, and similar legislation, would be allowed by the proposed convention. 
tort claims falling under the ATCA and the TVPA would come within the scope of the proposed convention, unless it provides otherwise.

Coupled with all of these benefits, however, is the potential for significant impairment of U.S. laws used to attempt to remedy violations of fundamental human rights. In the words of Professor Paul Dubinsky in a paper on behalf of the International Association of Democratic Lawyers (IADL) submitted to the Hague Conference drafting the proposed convention, "The IADL asks that in negotiating a convention on jurisdiction and recognition and enforcement of judgments, the delegates of the Hague Conference do so in a way that does not roll backwards the progress that international human rights law has made in the last few decades." ${ }^{\circ 1} \mathrm{~A}$ brief look at the proposed convention will demonstrate why some are concerned.

\section{B. Formats for a Judgments Convention-Simple, Pure Double, and Mixed Double}

A variety of formats may be considered in drafting a jurisdiction and judgments convention. On the one hand, two "simple" conventions could be used-one to address solely jurisdiction, and another to address solely the enforcement and recognition of judgments. Because of the "symbiotic relationship... between adjudicatory authority and enforcement of foreign judgments, ${ }^{, 82}$ a "double" convention addressing both jurisdiction and the recognition and enforcement of judgments is desirable. ${ }^{83}$ A "pure" double convention has two "lists" regarding jurisdiction-a required list and a prohibited list. ${ }^{84}$ Under a pure double convention, a court in a contracting state is required to hear a case based on a jurisdictional

81. See Dubinsky, supra note 54.

82. Arthur T. von Mehren, Enforcing Judgments Abroad: Reflections on the Design of Recognition Conventions, 24 BROOK. J. INT'L L. 17, 18 (1998) (“[R]ecognition conventions almost invariably impose a jurisdictional test.").

83. Part of the desirability of a double convention lies in its fairness to both plaintiffs and defendants. See id. at 24 . Simple conventions regulating only enforcement and recognition often are more advantageous to plaintiffs than to defendants. See id. (explaining that simple conventions regulating only enforcement and recognition do not allow the defendant to know with certainty where it could be sued, while they allow the plaintiff to know exactly where a judgment can be enforced or recognized). As a result, a properly constructed simple convention might actually be more beneficial to human rights advocates than a double convention, although at the expense of discriminating against defendants in human rights cases.

84. See id. at 19. 
ground found on the "required" list but is barred from deciding a case based on a jurisdictional ground found on the "prohibited" list. ${ }^{85}$ The European Union's Brussels Convention on Jurisdiction and the Enforcement of Judgments in Civil and Commercial Matters ${ }^{86}$ and the related Lugano Convention ${ }^{87}$ operate as pure double conventions, at least with regard to EU defendants. ${ }^{88}$

Despite the enhanced predictability that would result in jurisdiction, enforcement, and recognition of judgments under a pure double convention, the strict nature of pure double conventions often presents difficulties for negotiators in deciding what to require and what to prohibit. ${ }^{89}$ A more flexible approach that avoids some of these problems, though at the expense of some of the predictability of a jurisdiction convention, is the mixed double convention. ${ }^{90} \mathrm{~A}$ mixed double convention contains a required list (a "white list") and a prohibited list (a "black list") of jurisdictional bases similar to the pure double convention, but also has a third "permitted" list (a "gray list"). ${ }^{91}$ The permitted list would consist of jurisdictional grounds not enumerated in the required or prohibited lists and would allow, but not require, a contracting state's court to exercise jurisdiction; neither exercising nor failing to exercise jurisdiction over a defendant on a "permitted" basis of jurisdiction would be a breach of the

85. See id. Certain limited or "rare" exceptions might apply to this hard and fast rule. See id.

86. Convention on Jurisdiction and Enforcement of Judgments in Civic and Commercial Matters, 1990 O.J. (C 189) 1 [hereinafter Brussels Convention].

87. European Free Trade Association: Convention on Jurisdiction and Enforcement of Judgments in Civil and Commercial Matters, 1988 O.J. (L 319) 9 [hereinafter Lugano Convention].

88. See von Mehren, supra note 82, at 20.

89. See id. at 25-26 (discussing how insistence on acceptance of jurisdictional grounds, coupled with differences in "social, sociological, political, and economic cultures," can create breakdowns in pure double convention negotiations).

90. I have chosen to use the terms simple, double, and mixed conventions, instead of the occasionally used French-derived terms, "convention simple," "convention double," and "convention mixte." Id. at 18-19. While the terms I use may slightly differ in connotation from the French, and may also sound like a tennis match (i.e., "mixed double convention"), I believe that they are a little easier to work with for present purposes.

91. See Friedrich K. Juenger, A Hague Judgments Convention?, 24 BRooK. J. INT'L L. 111, 118-19 (1998) (using the "white," "black," and "gray" terminology, and describing a mixed convention as a "crossbreed" between simple and double conventions); see also von Mehren, supra note 82, at 26 (explaining, from a drafting and implementation standpoint, some of the practical advantages of a mixed convention, which "divides jurisdictional bases-like Caesar's Gaul—into three parts: required, permitted, and prohibited"). 
convention..$^{92}$ As a function of the "symbiotic relationship" between jurisdiction and recognition and enforcement of judgments, however, the courts of the other contracting states would not be required to enforce or recognize judgments rendered on the basis of these "permitted" jurisdictional grounds.

\section{The Hague Convention in its Current Format}

Those negotiating the proposed Hague Convention have opted for the mixed double convention format. ${ }^{94}$ In the jurisdiction portion of the proposed convention, Article 17 states that "[s]ubject to Articles 4, 5, 7, 8, 12, and 13 [the 'required' list], the Convention does not prevent the application by Contracting States of rules of jurisdiction under national law, provided that this is not prohibited under Article 18." ${ }^{95}$ In the recognition and enforcement portion of the proposed convention, Article 24 provides that enforcement and recognition under the convention "shall not apply to judgments based on a ground of jurisdiction provided for by national law in accordance with Article 17." ${ }^{96}$ Otherwise, judgments rendered on required bases of jurisdiction are recognized and enforced in contracting states, ${ }^{97}$ and judgments rendered on prohibited bases of jurisdiction are not only refused automatic recognition or enforcement in other contracting states, but are per se violations of the convention by the contracting

92. The more flexible mixed convention would not require judges to apply one set of jurisdictional rules for a case with domestic parties and another set when a party is foreign; the burden would be on the plaintiff to choose a "sound, rather than marginal" ground of jurisdiction, i.e., one from the required list, if it wanted to have the judgment automatically enforced or recognized in other contracting states. Von Mehren, supra note 82, at 26-27 (discussing "two quite different [adjudicatory] regimes" that would result under a strict double convention).

93. See id. at 26 .

94. See ALI Report, supra note 7, at 9-10. The Working Group that emerged from the proposal by the United States to develop the present convention "recognised that a simple Convention ... would be insufficient even though, in the wider context of the Conference ... a full double Convention would be too ambitious." CATHERINE KESSEDJIAN, INTERNATIONAL JuRISDiction AND Foreign Judgments IN Civil AND COMMERCIAL MATTERS, No. 18 (Hague Conference on Private Int'l Law Preliminary Document No. 7, Apr. 1997) (citations omitted), available at http://www.hcch.net/e/workprog/jdgm.html (on file with the Duke Law Journal).

95. Proposed Convention, supra note 7, art. 17.

96. Id. art. 24.

97. See id. art. 25. 
state whose court obtained jurisdiction based on a prohibited ground..$^{98}$

The "black" list of prohibited grounds of jurisdiction in the current draft includes jurisdiction "exercised by the courts of a Contracting State on the basis solely of ... the service of a writ upon the defendant in that State." ${ }^{, 99}$ In other words, the often controversial ground of transient or "tag" jurisdiction is prohibited under the proposed convention. ${ }^{100}$ Equally of interest in the current version's jurisdiction section is an express exception to the prohibited list for actions alleging violation of human rights. ${ }^{101}$ As the following part illustrates, these inclusions could impact ATCA and TVPA litigation.

\section{ANALYSIS}

The negotiators could arrive at a variety of possible outcomes with regard to the convention and any human rights provisions it

98. See id. art. 26. Note that the proposed convention would apply to civil and commercial suits (with some enumerated exceptions, such as wills, social security, and marital relations, see $i d$. art. $1, \S 2)$, unless all of the parties before the court habitually reside in that state. See id. art. $2, \S 1$. Thus, when the parties are "purely domestic," the convention's jurisdictional white and black lists do not apply. However, when one of the parties is foreign, whether or not habitually resident in a contracting state, the convention's jurisdictional white and black lists apply, regardless of whether enforcement is sought outside of the country or not.

99. Id. art. 18 .

100. See Clermont, supra note 63, at 111-12 ("[Tag jurisdiction] has long been the recipient of criticism from academics and foreigners alike.").

101. Article 18, section 3 of the current draft of the proposed convention reads:

Nothing in this Article shall prevent a court in a Contracting State from exercising jurisdiction under national law in an action [seeking relief] [claiming damages] in respect of conduct which constitutes-

[Variant One:

[a) genocide, a crime against humanity or a war crime[, as defined in the Statute of the International Criminal Court]; or]

[b) a serious crime against a natural person under international law; or]

[c) a grave violation against a natural person of non-derogable fundamental rights established under international law, such as torture, slavery, forced labour and disappeared persons].

[Subparagraphs [b) and] c) above apply only if the party seeking relief is exposed to a risk of a denial of justice because proceedings in another State are not possible or cannot reasonably be required.]

Variant Two:

a serious crime under international law, provided that this State has established its criminal jurisdiction over that crime in accordance with an international treaty to which it is a party and that the claim is for civil compensatory damages for death or serious bodily injury arising from that crime.]

Proposed Convention, supra note 7 , art. $18, \S 3$. 
might contain. ${ }^{102}$ The following sections seek to explain some of these possible outcomes and to illustrate how each might affect the use of the ATCA and the TVPA to remedy human rights violations abroad.

As a brief overview, first of all, if the proposed convention retains its current format, it might not have a tremendous impact on the ATCA and the TVPA, but depending on how it is interpreted in the courts, it could limit, or enhance, this type of litigation. Second, the negotiators could eliminate the human rights exception from the proposed convention, which could effectively nullify human rights legislation like the ATCA and the TVPA. On the other hand, the absence of a human rights exception might not dampen human rights litigation at all. Third, the proposed convention could be drafted to make current human rights litigation more effective without compromising concerns of due process and fairness to defendants by effectively placing certain forms of otherwise exorbitant jurisdiction, when used in a human rights context, on the white list of jurisdictional grounds and requiring enforcement and recognition of judgments in these circumstances.

Furthermore, the negotiators could consider steps that would increase the eventual participation in the convention, which would strengthen its ability to assist in enforcing human rights. Above all, the negotiators should understand that the final version of the proposed convention, in whatever form it takes, could significantly impact international human rights litigation via the ATCA and the TVPA. ${ }^{103}$

\section{A. The Convention Could Retain a Human Rights Exception to the Jurisdictional Black List as in the Current Draft}

As mentioned above, the current draft of the convention has an exception to the prohibited list of jurisdictional bases for human rights cases, effectively allowing a contracting state to exercise

102. At the time of publication of this Note, the Hague Conference had scheduled two meetings to take place concerning the negotiation of the proposed convention, one to occur in mid-2001, and the other to fall in late 2001 or early 2002. See Preliminary Draft Convention on Jurisdiction and Foreign Judgments in Civil and Commercial Matters, Hague Conference on Private International Law (Oct. 30, 1999), Hague Conference on Private International Law, available at http://www.hcch.net/e/workprog/jdgm.html (on file with the Duke Law Journal).

103. See Dubinsky, supra note 54 ("Whether or not the Hague Conference is willing to endorse such a role [of enforcing human rights] for national courts, it is crucial that it not stand in the way of these efforts by its member states to implement their duties under human rights treaties."). 
jurisdiction over individuals on the basis of national law in human rights cases. ${ }^{104}$ The jurisdictional exception for human rights cases is important because tag jurisdiction is prohibited in all other cases to which the proposed convention would apply. ${ }^{105}$ Apparently, concerns have been raised in the negotiations about the application of the convention to human rights litigation. ${ }^{106}$

Plaintiffs bringing civil actions in the United States based on the ATCA and the TVPA frequently use tag jurisdiction, ${ }^{107}$ often because there is no other way to gain jurisdiction-ATCA and TVPA defendants are often citizens and residents of foreign countries and have no substantial contacts or property in the United States. ${ }^{108}$ As a result, if a defendant who does not have immunity or who has waived it happens to come to the United States and is served with process, jurisdiction has been gained. ${ }^{109}$

On the subject of enforcement and recognition of human rights cases, however, the case is not as clear cut. The current draft of the proposed convention simply states that the chapter on recognition and enforcement "shall not apply to judgments based on a ground of jurisdiction provided for by national law in accordance with Article 17." Article 17, in turn, provides that "the Convention does not

\footnotetext{
104. See Proposed Convention, supra note 7, art. 18.

105. See id. art. 18, §2(f).

106. See, e.g., Dubinsky, supra note 54 (submitted on behalf of the International Association of Democratic Lawyers to the Special Commission to heighten awareness of the potential application of the proposed convention to human rights litigation); see also CATHERINE KESSEDJIAN, SyNTHESIS OF THE WORK OF THE SPECIAL COMMISSION OF MARCH 1998 ON INTERNATIONAL JURISDICTION AND THE EFFECTS OF FOREIGN JUDGMENTS IN CIVIL AND Commercial Matters, No. 67 n.53 (Hague Conference on Private Int'l Law Preliminary Document No. 9 (July 1998)) ("Nowadays, [tag] jurisdiction seems to be used to attempt to obtain civil damages even where the victim [of a violation of human rights committed abroad] does not reside in the country in which the court exercises jurisdiction. It is not clear that such actions are covered by the Convention."), available at http://www.hcch.net/e/workprog/

jdgm.html (on file with the Duke Law Journal).

107. See Clermont, supra note 63, at 112 .

108. Plaintiffs have a due process right to have their claims heard, and under current Supreme Court doctrine, tag jurisdiction is allowed to satisfy this right. See Harold G. Maier, A Hague Conference Judgments Convention and United States Courts: A Problem and a Possibility, 61 ALB. L. REV. 1207, 1235-36 (1998) (arguing that reasonable, permissive rules allowing tag jurisdiction would align with the Supreme Court's attitude towards jurisdictional rules).

109. See supra note 60 and accompanying text (regarding the use of tag jurisdiction in specific ATCA and TVPA cases).

110. Proposed Convention, supra note 7, art. 24 (Chapter 3-the chapter on recognition and enforcement-does not apply to judgments based on a "non-white list" ground of jurisdiction provided for by national law.).
} 
prevent the application by Contracting States of rules of jurisdiction under national law, provided that this is not prohibited under Article 18." ${ }^{\prime 11}$ What this all means, considering the human rights exception to Article 18, is that contracting states can always exercise jurisdiction on an otherwise prohibited ground of jurisdiction in a human rights case, but that the other contracting states are under no affirmative obligation to enforce or recognize the judgments in these circumstances. The current approach reflects the fundamental nature of having a gray list; jurisdictional grounds on the gray list are permitted but do not require enforcement and recognition in other contracting states. ${ }^{112}$

The current version of the proposed convention would not necessarily roll back domestic efforts at remedying human rights violations but would just maintain the status quo of ATCA and TVPA judgment enforcement and recognition abroad. ${ }^{113}$ It would not allow these types of claims to have the routine enforcement in contracting states that standard commercial judgments would enjoy under the proposed convention. ${ }^{114}$ Practically speaking, the bottom line is that the human rights exception of the current draft of the convention would do nothing to increase the enforcement and recognition of ATCA and TVPA judgments in contracting states. ${ }^{115}$

Similarly at issue is the future of other procedures used in foreign countries that might be useful in the human rights context. ${ }^{116}$ For

\footnotetext{
111. Id. art. 17.
}

112. See von Mehren, supra note 82, at 26-27 (discussing the operation of the gray list in a mixed convention).

113. This status is not all that good for human rights advocates. See Charles F. Marshall, Reframing the Alien Tort Act After Kadic v. Karadzic, 21 N.C. J. INT'L L. \& COM. REG. 591, 617 (1996) (explaining the current unlikelihood of having an ATCA judgment enforced or recognized abroad).

114. Unless, of course, the jurisdiction were based on a required, "white list" ground of jurisdiction, which seems unlikely given the practical realities of the ATCA and the TVPA.

115. In this sense, the human rights exception has taken what would otherwise be an exorbitant basis for jurisdiction, and bumped it into the permitted list, demonstrating the "crossbreed" nature of a mixed convention. See Juenger, supra note 91, at 118 . When the human rights exception to the prohibited list applies, the convention operates as a simple convention, a treaty governing only recognition and enforcement, since exercise of jurisdiction on otherwise prohibited grounds is not a breach. As noted elsewhere, this system has notable benefits in terms of flexibility and application. See von Mehren, supra note 82, at 26-27.

116. See Catherine Kessedjian, Note on Provisional and Protective Measures in Private InTERnational LaW AND Comparative LaW No. 5 (Hague Conference on Private Int'l Law Preliminary Document No. 10, Oct. 1998) (explaining how the availability of certain protective measures in foreign courts is a matter of interest to the Special Commission), available at http://www.hcch.net/e/workprog/jdgm.html (on file with the Duke Law Journal). 
example, English courts (and American courts as well) have procedures for ordering the repatriation of a debtor's assets from other countries, a mechanism that applies to human rights litigants and that might be affected by the outcome of the convention. ${ }^{117}$ Furthermore, English law provides that a defendant can be served with an order even if he is physically located outside of the jurisdiction, as long as the case has sufficient connection to the English legal system. ${ }^{118}$ Professor Dubinsky explains that this leave to serve a defendant exists in the case of a victim sustaining personal injuries in violation of various human rights treaties. ${ }^{119}$ Furthermore, a number of jurisdictional bases that made their way onto the black list, grounds of jurisdiction based on the national laws of other contracting states, could be similarly effective in exercising jurisdiction over human rights defendants. ${ }^{120}$ Notably, the United States is not the only country expressing some concern over the effect of the proposed convention on human rights litigation. ${ }^{121}$

The current form of the proposed convention arguably could still help human rights litigation, or, alternatively, hurt it. On the one hand, the prohibition on tag jurisdiction refers specifically to "jurisdiction ... on the basis solely of ... the service of a writ upon the defendant in that State." 122 Human rights litigation in the past may have involved defendants who already had substantial ties to the jurisdiction, such that personal jurisdiction would not be based "solely" on the service of a writ. For example, in Filartiga, the

\footnotetext{
117. See id. at No. 23.

118. See id. at No. 27

119. See Dubinsky, supra note 54.

120. For example, Article 14 of the French Civil Code grants jurisdiction on practically any action brought by a French citizen, regardless of the connection of the suit to France. See Clermont, supra note 63, at 92 (citing C. CIV. arts. 14-15 (Fr.)). Similarly, in Germany, the presence of a defendant's property, even of insignificant value, can serve as a basis for jurisdiction over the defendant on claims unrelated to the property. See RUDOLF B. SChlesinger, Comparative Law: CASES-Texts-Materials 242 (6th ed. 1998). The current version of the list of prohibited grounds of jurisdiction includes both the French and the German examples. See Proposed Convention, supra note 7, art. 18, § 2(a)-(b).

121. See, e.g., Attorney General's Department, International Jurisdiction and the Recognition and Enforcement of Foreign Judgments in Civil Matters: Draft Hague Convention Issues Paper (1999) (asking for views on whether Australia should support jurisdiction provisions in the convention that would affect tag jurisdiction and whether it should support the inclusion of a human rights provision), available at http://law.gov.au/publications/haguepaper (on file with the Duke Law Journal) [hereinafter International Jurisdiction Paper].

122. Proposed Convention, supra note 7, art. 18, § 2(f).
} 
defendant resided in New York at the time he was served. ${ }^{123}$ Other human rights defendants may have engaged in conduct that had enough impact in the United States such that minimum contacts with the jurisdiction can be established. Assuming this were the case, and that jurisdiction in a human rights case could actually be based upon a white list ground, the proposed convention would require any judgment rendered to be enforced and recognized in all of the other contracting states. Additionally, an increased likelihood of enforcement and recognition abroad could result from the phenomenon present in mixed conventions that plaintiffs tend to make sure jurisdiction is based on a well-founded ground of jurisdiction to ensure enforcement. ${ }^{124}$

On the other hand, even in its current format the proposed convention could hinder human rights litigation. For example, a judge might read the human rights exception too narrowly and hold that the proposed convention prohibits the court from having jurisdiction in cases of tag or other exorbitant grounds of jurisdiction. As a result, in cases where domestic law would otherwise allow personal jurisdiction, if the facts were believed to put the case outside of a narrowly read human rights exception, the court would feel obligated by the proposed convention to dismiss. Of course, there is the potential for the alternative problem: judges might read the human rights exception too broadly by regarding an ordinary tort as a "serious crime against a natural person under international law" 125 and subject residents of contracting states to exorbitant grounds of jurisdiction where the proposed convention would otherwise prohibit it. Given these considerations, the current form of the proposed convention, even with its human rights exception, could affect ATCA and TVPA litigation. ${ }^{126}$

123. See Filartiga v. Pena-Irala, 630 F.2d 876, 878-79 (2d Cir. 1980).

124. See supra note 92 (explaining that the plaintiff must choose a "sound, rather than marginal" ground of jurisdiction, i.e., one from the required list, if it wanted to have the judgment automatically enforced or recognized in other contracting states); see also von Mehren, supra note 82, at 26-27 (discussing "two quite different regimes" that would result under a strict double convention).

125. Proposed Convention, supra note 7 , art. $18, \S 3$.

126. An important additional consideration is that the Brussels and Lugano Conventions benefit from the ultimate interpretation of a single tribunal, namely the European Court of Justice, while the proposed convention would have no way to impose uniformity of interpretation, potentially exacerbating the problem of defining "human rights cases" too conservatively or liberally. See Traynor, supra note 8 , at 6 . 


\section{B. The Convention Could Contain No Human Rights Exception at All}

It may seem odd that a convention regulating judgments and jurisdiction could, by not even mentioning human rights, have any impact on human rights enforcement. ${ }^{127}$ The proposed convention, however, could significantly restrict use of the ATCA and the TVPA even if the proposed convention does not mention human rights at all.

The prohibition on tag jurisdiction in the proposed convention is what leads to the potentially destructive effect on the ACTA and the TVPA. ${ }^{128}$ Without a human rights exception, not only would ATCA and TVPA judgments based on tag or transient jurisdiction be barred from enforcement or recognition in any contracting state, but the exercise of jurisdiction over the defendant would be a per se breach of the convention, even if no foreign enforcement or recognition were sought. Previously ATCA and TVPA-friendly foreign states ${ }^{129}$ which ratified the convention would find themselves obligated to refuse enforcement and recognition, and the United States would be in breach if it allowed tag jurisdiction in ATCA and TVPA cases. ${ }^{130}$ In short, the human rights exception currently in the proposed convention does little if anything to increase human rights enforcement abroad, but in some way serves as a safeguard to prevent the ATCA and the TVPA from being rendered virtually useless.

However, the absence of a human rights exception might prevent some of the negative consequences the exception could generate if it were read too narrowly or broadly by the courts. In other words, if there is no human rights exception, that exception could not be abused in a way that would undermine some of the benefits of the proposed convention. ${ }^{131}$ Additionally, jurisdiction in many human rights cases can be based upon more than simple tagging, ${ }^{132}$ meaning

127. Cf. Amley, supra note 4, at 2210 (explaining that it is "not surprising" that overseas validation of ATCA judgments is closely tied to "today's human rights agenda").

128. This is evident from the text of the proposed convention, without a human rights exception. See supra note 101. Article 18, section 2(f) would prohibit tag jurisdiction in all cases involving a nonresident. See Proposed Convention, supra note 7, arts. 2, §1 and 18, §2(f).

129. See Amley, supra note 4, at 2180 (analyzing the current structural, legal, and political aspects of ATCA-friendly jurisdictions).

130. The proposed convention would by definition apply to the ATCA in most cases since an alien would be involved. See Proposed Convention, supra note 7, art. 2, § 1 .

131. See supra Part III.A.

132. For example, in the context of general civil and commercial matters, giving up tag jurisdiction may not be that big of a deal. See Clermont, supra note 63, at 111-12 ("Given 
that even if there is no human rights exception in the proposed convention, it might not roll back efforts at human rights enforcement to the degree some would think.

\section{The Convention Could Be Drafted to Allow Greater Enforcement of Human Rights Judgments Without Compromising Due Process for Defendants}

The previous sections explained how the proposed convention could be drafted so that it would not hinder ATCA and TVPA actions. ${ }^{133}$ While it might alter the fundamental nature of the proposed convention by making an affirmative statement, the proposed convention could be drafted in a way to enhance human rights litigation around the world. In short, the negotiators could include a human rights exception in the enforcement and recognition of judgments section, such that a judgment involving human rights would have to be enforced and recognized in all contracting states, even if the basis of jurisdiction was otherwise prohibited. ${ }^{134}$

Obviously, if ATCA and TVPA judgments rendered in the United States were required to be enforced and recognized in all of the other contracting states, human rights litigation would have a much greater impact. In many ways, however, making enforcement and recognition of human rights judgments mandatory presents some problems with regard to the due process and fairness accorded to defendants. Contracting states would have no assurance that the judgment they were required to enforce and recognize was based on a reasonable ground of jurisdiction. The only criterion a court would be allowed to consider would be whether the case involved human

transient jurisdiction's dubious propriety and general unnecessariness, the United States should be, and seems to be, willing to accept the treaty's prohibition.”). While human rights cases tend to make use of tagging jurisdiction very frequently, they might not necessarily have to rely solely on it as a means of obtaining jurisdiction. See supra notes 123-24 and accompanying text (explaining how defendants in human rights cases may already have substantial ties to the jurisdiction).

133. See Dubinsky, supra note 54 (explaining that the proposed convention should "not stand in the way of these efforts by its member states to implement their duties under human rights treaties").

134. One place where this could be done is in Article 25 of the proposed convention, by adding: "Any judgment regarding a violation of a fundamental human right shall be recognized or enforced under this Chapter, regardless of whether the jurisdiction was obtained on the basis of national law." The human rights exception in the proposed convention also merely allows, but does not require, a court to exercise jurisdiction on the basis of national law in a case involving human rights. However, national laws still might require courts to have jurisdiction on certain grounds not prohibited by the proposed convention. 
rights. In addition, this could lead to courts narrowly interpreting the human rights exception in an effort to refuse enforcement of a judgment perceived to have an unreasonable basis of jurisdiction.

A way to alleviate these problems, yet still retain some of the advantages of a human rights provision in the enforcement and recognition section, would be to require enforcement and recognition of human rights cases like those based on the ATCA and the TVPA not only when based upon the white list grounds of jurisdiction, but also when based on selected grounds of jurisdiction, otherwise deemed exorbitant, which have proven the most essential in human rights litigation. For example, the proposed convention's Article 25, which explains which judgments "shall be recognised or enforced," could provide that a judgment in a case where a plaintiff alleges a violation of a fundamental human right, subject to the definition of such a case already given in Article 18, shall be enforced or recognized if based on a ground of jurisdiction provided for in Articles 3 to 13 (the white list) or if based on the presence of the defendant in the jurisdiction, the presence of property of the defendant in the jurisdiction, or the nationality of the plaintiff. ${ }^{136}$

This alternative would make the proposed convention a much more effective tool for human rights litigants but should help to avoid concerns of overreaching and unreasonable assertions of jurisdiction. First, by selecting only the most necessary forms of jurisdiction for human rights litigation, the negotiators would be recognizing the extreme difficulty of obtaining jurisdiction over human rights violators, while stopping short of requiring courts to enforce and recognize a judgment based on any exorbitant national ground of jurisdiction. Second, courts would always have the safeguard of recognizing that the case was not one alleging a violation of human rights, depending on the broad or narrow reading of the term. In other words, if a court felt that jurisdiction over a defendant was unwarranted or unreasonable under the convention, it may be because the activity did not amount to the level of a human rights violation. ${ }^{137}$ The court would therefore be able to refuse recognition

135. Proposed Convention, supra note 7 , art. $25, \S 1$.

136. These are simply examples of otherwise exorbitant grounds of jurisdiction that may prove useful in the human rights context, given the difficulty of obtaining jurisdiction via the grounds enumerated in the white list. See supra note 120 (providing examples of currently blacklisted grounds of jurisdiction in use in France and Germany, which could be useful in a human rights context).

137. Furthermore, it is important to remember that under the jurisdictional section of the 
and enforcement in "ordinary" tort cases based on exorbitant grounds of jurisdiction.

Third, the proposed convention does contain an exception that would give a court the right to deny recognition or enforcement for a number of reasons, including if the "judgment results from proceedings incompatible with fundamental principles of procedure of the State addressed, including the right of each party to be heard by an impartial and independent court," obtained by fraud in connection with a matter of procedure," ${ }^{139}$ or if "recognition or enforcement would be manifestly incompatible with the public policy of the State addressed."140 These provisions allow some flexibility in the event a court felt uncomfortable automatically enforcing or recognizing a somewhat suspect judgment.

Finally, an additional provision could be inserted into the proposed convention requiring a plaintiff alleging a human rights violation to post bond covering the costs incurred by the defendant should the initial court decline jurisdiction or should any subsequent court decline enforcement or recognition. This final recommendation could quell fears that defendants in human rights cases were being unfairly subjected to lawsuits and proceedings around the world.

If it seems radical to require enforcement and recognition of human rights judgments on the basis of certain otherwise exorbitant grounds of jurisdiction, it is in many ways the approach taken by the European Union's Brussels and Lugano Conventions with respect to non-EU defendants. The Brussels and Lugano Conventions maintain a required list and a prohibited list of grounds of jurisdiction ${ }^{141}$ but have a "radical" and discriminatory effect on non-EU defendants. ${ }^{142}$ While jurisdiction can only be gained over defendants from EU countries according to the required list, jurisdiction over non-EU

proposed convention, contracting states, because of the current exception for human rights cases, are prohibited from using exorbitant grounds of jurisdiction in non-human rights cases involving nonresidents. Thus, a country runs the risk of breaching the convention if its courts are exercising jurisdiction exorbitantly in non-human rights cases. This result may explain in part why courts might give a narrow reading to the human rights exception in the current form of the proposed convention, see supra Part III.A, potentially undermining human rights litigation.

138. Proposed Convention, supra note 7 , art. $28, \S 1$ (c).

139. Id. art. $28, \S 1(\mathrm{e})$.

140. Id. art. $28, \S 1(\mathrm{f})$.

141. There are, however, no permitted lists. When the conventions apply, jurisdiction is either required or it is prohibited. See Clermont, supra note 63, at 93.

142. See von Mehren, supra note 82, at 20. 
defendants can be exercised on the basis of any national law, even if it would otherwise fall within the prohibited list. ${ }^{143}$ The real bite, however, and similarity to the proposal offered here, is that judgments against non-EU defendants premised upon national law, even if prohibited under the convention as to EU defendants, will receive automatic enforcement in each Brussels/Lugano-conventioncontracting state..$^{144}$ Furthermore, the enforcing court would not be allowed an opportunity to review the jurisdiction of the rendering court or to apply a public policy test, both of which are allowed when the judgment concerns an EU defendant. ${ }^{145}$

This version of a human rights exception to the proposed convention, which would apply to the enforcement and recognition section as well as the jurisdictional section, would operate with the same Brussels and Lugano discriminatory effect, yet here it would be aimed at human rights cases as opposed to non-EU defendant cases. Not only would contracting states be allowed to use certain named, otherwise exorbitant, grounds of jurisdiction in human rights cases, but judgments rendered on this basis would receive automatic recognition and enforcement in all contracting states.

Of course, the signatories of the Brussels and Lugano Conventions may have had little reluctance in including the discriminatory provision, simply because they knew it would never apply to its own nationals as defendants. If the negotiators of the proposed convention allowed such discrimination vis-à-vis human rights defendants, some of the defendants could actually end up being nationals of contracting states. In other words, if a country signs the convention with the proposal, its own courts could be obligated to enforce a human rights judgment rendered against one of its own nationals in another country's court on what might be viewed as an exorbitant basis of jurisdiction, which might be an unrealistic alternative. ${ }^{146}$

143. See Brussels Convention, supra note 86, art. 4; Lugano Convention, supra note 87, art. 4. The current human rights provision in the proposed convention would have at least this effect with regard to human rights cases, as opposed to non-EU defendants' cases under the Brussels and Lugano Conventions.

144. See Brussels Convention, supra note 86, arts. 26, 28; Lugano Convention, supra note 87, arts. 26, 28.

145. See von Mehren, supra note 82, at 20-21.

146. It is also important to realize that a Brussels/Lugano-type discriminatory provision in the proposed convention has the potential to backfire. For example, if one country agrees to the use of such a discriminatory provision, but then disagrees with the terms of another provision in the convention, it might feel compelled to choose between the lesser of two evils and join the 
This style of convention would have a major impact on the enforcement of human rights. ${ }^{147}$ Countries might be reluctant to allow so much use of jurisdictional laws from other nations in applying the convention, thereby undermining the goal of predictability, ${ }^{148}$ but the current draft of the proposed convention already does this to some extent by allowing the exception in the jurisdictional section. ${ }^{149}$ Furthermore, jurisdiction based on national laws would be based only on the specified, otherwise exorbitant, grounds of jurisdiction deemed essential in human rights cases, a small subset of the total cases brought, and thus might not really affect much of the predictability of the convention at all. ${ }^{150}$ Second, the negotiators do not need to follow the exact model of the Brussels and Lugano Conventions; the proposed convention could allow contracting states who are asked to recognize or enforce human rights judgments to review the grounds of jurisdiction of the rendering court and to refuse recognition or enforcement on public policy grounds, as is generally already allowed under the current draft of the proposed convention. ${ }^{151}$

If anything, because many of the Hague Conference members appear to be committed to the enforcement of human rights, ${ }^{152}$ the small yet important number of human rights cases that would be involved (coupled with the remaining and proposed protections for

convention even with the disagreeable provision, for fear that being outside of a convention with a discriminatory provision would be even more undesirable. Though in a somewhat different context, similar concerns were raised by the United States' objections to an International Criminal Court. See Norman Dorsen \& Morton H. Halperin, Editorial, Justice After Genocide, WASH. POST, May 13, 1998, at A17 (discussing President Clinton's need to calm fears of the U.S. military that the International Criminal Court might indict U.S. soldiers).

147. See Amley, supra note 4, at 2210 (discussing the importance of worldwide recognition and enforcement of judgments to human rights efforts).

148. See KESSEDJIAN, supra note 106, at No. 102.

149. See Proposed Convention, supra note 7 , art. $18, \S 3$.

150. Since expanded jurisdiction is permitted with all cases involving non-EU defendants (not just human rights) in the Brussels and Lugano Conventions, applying it just to human rights cases should not be a great concern.

151. The proposed convention stands in contrast to the Brussels and Lugano Conventions, which disallow these challenges when non-EU defendant judgments are concerned. See von Mehren, supra note 82 , at 20-21. With regard to a public policy exception, see Proposed Convention, supra note 7 , art. 28, § 1(f) (allowing refusal of recognition or enforcement if it would be "manifestly incompatible with the public policy of the State addressed").

152. See Dubinsky, supra note 54 (noting the international community's great interest in Pinochet's extradition and the willingness of Switzerland to locate and freeze his assets); Amley, supra note 4, at 2196 ("[T]he international community appears to place a higher premium on addressing human rights violations than it does on remedying contractual breaches and the commission of traditional torts."). 
defendants in these cases) would be well worth the great benefit of enforcing human rights the world over. ${ }^{153}$ This version of a human rights exception to the proposed convention allows the members of the Hague Conference to recognize that human rights litigation relies on certain grounds of jurisdiction that might otherwise be prohibited by the proposed convention and that, in many instances, use of such grounds may provide the only means of bringing human rights violators to court. ${ }^{154}$ Modifying the current human rights exception in this manner may be the necessary step in transforming what appeared to be simply a judgments and jurisdiction convention into another opportunity for the Hague Conference members to show their support for the emerging enforcement of human rights. ${ }^{155}$

\section{Increasing the Incentives to Participate While Enhancing Human Rights Enforcement}

If the previous alternative proves unacceptable, the proposed convention could allow for a similar "Brussels/Lugano-type" discriminatory effect, but on the basis of the defendant's residence in a noncontracting state. In the current version of the proposed convention, Article 2 provides that the jurisdictional white and black lists "shall apply in the courts of a Contracting State unless all the

153. There might be some U.S. constitutional problems with these proposals, since a U.S. court might be asked to enforce a judgment that was based on an unconstitutional ground of jurisdiction. See Ronald A. Brand, Tort Jurisdiction in a Multilateral Convention: The Lessons of the Due Process Clause and the Brussels Convention, 24 BRoOK. J. INT'L L. 125, 126 (1998). Concerns about the Constitution trumping treaty provisions is a major issue being discussed with respect to the proposed convention. See Stanley E. Cox, Why Properly Construed Due Process Limits on Personal Jurisdiction Must Always Trump Contrary Treaty Provisions, 61 ALB. L. REV. 1177, 1179 (1998) (one of a series of articles submitted as a part of Albany Law Review's 1998 symposium entitled "Could a Treaty Trump Supreme Court Jurisdictional Doctrine," reprinted in Volume 61 of the Albany Law Review).

154. In fact, while many object to tag jurisdiction because of the lack of relation between the defendant and the forum, one could argue that violation of fundamental human rights and of the law of nations impacts forums around the world. While this is a potentially arrogant argument, it was successful in Filartiga. See Kim, supra note 25 (discussing transitory torts and the Filartiga court's conclusion that "liability for certain tortious acts follow[s] the tortfeasor, such that he could be subject to suit for [the acts] in any forum"); supra note 26 and accompanying text (explaining the doctrine of transitory torts).

155. Instead of a human rights exception, one could go even a step further by putting a human rights requirement on the white required list, such that jurisdiction would have to be recognized if the claim was of a violation of fundamental human rights. Such a result is probably not likely, because it would raise problems if judges felt it better to exercise discretion and decline jurisdiction on forum non conveniens or political question grounds, but were not allowed to because of the convention. See, e.g., Clermont, supra note 63, at 118-19 (reviewing arguments against forum non conveniens and, more broadly, discretionary jurisdiction). 
parties are habitually resident in that State, ${ }^{, 156}$ and that the proposed convention applies "to the recognition and enforcement in a Contracting State of a judgment rendered in another Contracting State." ${ }^{157}$ The proposed convention therefore requires courts in contracting states to apply the white list of jurisdictional grounds to cases where at least one of the parties is not resident in that state, even if that party is not from a contracting state. On the other hand, residents of noncontracting states do not receive the benefit of the prohibitions on blacklisted grounds of jurisdiction. ${ }^{158}$

Even though residents of noncontracting states can be subject to the black list of prohibited jurisdictional grounds, the proposed convention does not allow residents of contracting states to have judgments against residents of noncontracting states based on the blacklisted grounds automatically enforced and recognized in all contracting states. ${ }^{159}$ In fact, the proposed convention does not allow automatic enforcement and recognition of judgments against noncontracting state defendants when jurisdiction is based on any non-white ground. ${ }^{160}$

If the proposed convention opted for the framework of the Brussels and Lugano Conventions, it could require contracting states to enforce and recognize judgments against noncontracting state defendants, regardless of whether the jurisdiction was based on any non-white ground or on the basis of national law. ${ }^{161}$ The ability of the enforcing or recognizing court to review the jurisdiction of the rendering court or to apply a public policy exception could be retained. ${ }^{162}$

Interestingly, the white list of jurisdictional grounds in the proposed convention applies to all cases in contracting states involving nonresidents, whether or not the nonresident is a resident of a contracting state. ${ }^{163}$ The application of the convention to all

\footnotetext{
156. Proposed Convention, supra note 7, art. 2, § 1.

157. Id. art. $2, \S 2$.

158. See id. art. 18, $\S 1$ (explaining that "[w]here the defendant is habitually resident in a Contracting State, the application of a rule of jurisdiction provided for under the national law of a Contracting State is prohibited if there is no substantial connection between that State and the dispute," and listing "[i]n particular" the black list of jurisdictional grounds).

159. See id. art. 24.

160. See id.

161. See supra notes 141-45 and accompanying text.

162. See, e.g., Proposed Convention, supra note 7, art. 18, §3.

163. See Proposed Convention, supra note 7, art. 2 , § 1.
} 
foreigners might be intended to harmonize jurisdiction around the world where foreign litigants are concerned, in order to protect all foreign defendants. ${ }^{164}$ Contrary to the possible goals of harmonization and protection of defendants, though, the current draft of the proposed convention might actually undermine these efforts by creating a free-rider problem. In other words, states considering signature and ratification of the convention might realize that, even if they do not sign the convention, their residents would still receive some of the benefits of enhanced certainty regarding jurisdiction within the contracting states.

Changing Article 2, section 1 to apply only to residents of contracting states, however, could ensure greater participation in the proposed convention, with a side effect being the increased enforcement and recognition of ATCA and TVPA awards. ${ }^{165}$ According to this change, residents of noncontracting states would not get the benefit of the certainty created by the proposed convention's jurisdictional white list. ${ }^{166}$ In fact, an earlier version of the proposed convention provided that the lists would apply "in matters of jurisdiction... when the court seized is located in a Contracting State and the defendant is domiciled (or has his habitual residence) in a Contracting State." ${ }^{167}$ Increasing the incentives to join the convention could mean more participants. ${ }^{168}$ In turn, the more

164. See KessedjIAN, supra note 106, at No. 11 ("the defendant is at the Convention's centre of gravity").

165. A revised Article 2, section 1 could read, "The provisions regarding jurisdiction in this convention shall apply in the courts of a Contracting State if any of the parties involved is habitually resident in a Contracting State."

166. Contrary to Professor Clermont's implication, the Brussels Convention, which does not apply its jurisdictional requirements to defendants from noncontracting states, is not discriminatory to outsiders because of this exclusion from the benefit of the jurisdictional lists. See Clermont, supra note 63, at 93 . This exclusion simply recognizes that the noncontracting states were not present to negotiate the lists. Rather, it is the fact that judgments rendered against defendants from noncontracting states are automatically enforceable in all of the contracting states, regardless of the grounds of jurisdiction, that makes the Brussels Convention discriminatory. This is because, as Professor von Mehren points out, "[w]here non-domiciliary defendants are concerned, Brussels and Lugano function as simple or single conventions," that is, conventions dealing only with enforcement and recognition and not jurisdiction. von Mehren, supra note 82 , at 20 .

167. Issues Paper Draft Hague Convention-Attachment A, Article 2, variant 3.1, available at http://law.gov.au/publications/haguepaper/attacha.html\#art2 (last visited Oct. 6, 2000) (on file with the Duke Law Journal).

168. See KessedjIAN, supra note 116, at No. 11 ("This system could also encourage third States to ratify the Convention."); International Jurisdiction Paper, supra note 121, at 7.9 ("It has been argued that... it should be left open to Contracting States to exercise jurisdiction 
participants there are in the convention, the more places there are that a judgment can be enforced, whether a human rights case or any other case for that matter. ${ }^{169}$

\section{E. What If the United States Chooses Not to Be Part of the Convention?}

The foregoing discussion made two assumptions: that the convention would be achieved ${ }^{170}$ and that the United States would become a contracting state. But the United States, either at the negotiating level or at home during a ratification process, could refuse to join the convention. ${ }^{171}$ As the convention stands now, U.S. abstention would not significantly hamper human rights efforts on the domestic front, because, as noted above, ${ }^{172}$ the convention's jurisdictional human rights exception can be viewed as doing nothing to advance or roll back U.S. efforts at human rights enforcement via the ATCA and the TVPA. However, failure to join the contracting states could conceivably be detrimental to U.S. efforts to have judgments enforced abroad because of a perception by foreign courts of a lack of cooperation by the United States. Furthermore, if the negotiators were to adopt any of the geographically based discriminatory effects described above $\mathrm{e}^{173}$ and the United States were an outsider to the final convention, then U.S. litigants could truly be "whipsawed" 174 in all areas of the law, not just human rights litigation. Therefore, the United States needs to keep in mind that whatever proposals are entertained and whether or not it becomes a party, it has a substantial stake in the outcome of this convention.

according to their national laws against defendants habitually resident in non Contracting States. This would encourage non Contracting States to join the Convention.").

169. A recent report by the American Law Institute explained that the "provisions on 'Scope of Application of the Convention' (Art. 1 and 2) ... may need further attention." ALI Report, supra note 7, at 10.

170. It is worth pointing out that, in light of the cited benefits of a judgments convention, see supra notes 77-79, there is sufficient desire to make the convention a reality. But cf. Carrington Conversation, supra note 35 (expressing the view that the regulation of jurisdiction, enforcement, and recognition in U.S. state and federal courts is an inappropriate subject matter for a treaty).

171. This would be particularly ironic, since the current convention was proposed by the United States. See KeSSEDJIAN, supra note 94, at No. 17.

172. See supra note 113 and accompanying text.

173. See supra notes 161-64 and accompanying text.

174. Clermont, supra note 63, at 94 (explaining how the U.S. is treated under the Brussels and Lugano Conventions). 


\section{CONCLUSION}

The process of negotiating a Hague jurisdiction and judgments convention is a significant undertaking, and all parties involved should be commended for the steps that have already been taken. ${ }^{175}$ The benefits of a judgments convention have been well documented. ${ }^{176}$ One of the potential consequences, apart from possible constitutional conflicts and having to reorganize domestic jurisdictional law, ${ }^{177}$ is the effect of the proposed convention on domestic efforts to enforce human rights around the world, via the ATCA, TVPA, and other similar legislation. The foregoing discussion attempted to present some of the possible structures the final convention could take, and the potential consequences these structures could have on ATCA and TVPA actions, and on human rights litigation in other parts of the world.

If anything, the negotiators should be aware that a project such as the proposed convention, in whatever form it eventually takes, could positively or negatively impact ATCA and TVPA litigation. First of all, keeping a human rights provision as it appears in the current draft of the proposed convention should not do anything to adversely affect human rights litigation, but even then there is room for argument that it could help or hurt. Second, if the proposed convention removes its current human rights exception, it could hinder human rights enforcement. On the other hand, the convention could still be beneficial to human rights litigation in this form, since in many ATCA cases one could claim that jurisdiction was based on more than just a tagging basis. ${ }^{178}$ Finally, the proposed convention could allow the automatic enforcement and recognition of judgments in human rights cases when jurisdiction is based on an approved white list ground, or when based on an approved ground that would be exorbitant outside of a human rights setting. Furthermore, in many ways independent of the use of a human provision, the proposed convention could make its jurisdiction, enforcement, and recognition

175. See Brand, supra note 153 , at 127 (forming the assumption that "[t]he parties participating in the work of the Hague Conference ... are ready and willing to try hard to make a success of the negotiations, and are serious about the effort").

176. See supra notes 77-79.

177. See supra notes 79, 153 and accompanying text.

178. See Clermont, supra note 63, at 111-12 ("Given transient jurisdiction's dubious propriety and general unnecessariness, the United States should be, and seems to be, willing to accept the treaty's prohibition."). 
sections openly discriminatory to noncontracting states in the style of the Brussels and Lugano conventions.

All of this being said, these are simply paths that the proposed convention could follow. Perhaps none of these options will be the exact direction the proposed convention should or will take. The current version of the proposed convention, or even one without a specific human rights exception, could arguably assist human rights litigation. Furthermore, as a pragmatic matter, the potential for backfire of a more aggressive Brussels/Lugano-type discriminatory provision could break down agreement on the convention, making introduction of such a provision undesirable. Above all, it is important to remember Judge Robb's comment in Tel-Oren $v$. Libyan-Arab Republic, ${ }^{179}$ an ATCA case, that "[i]t is one thing for a student note-writer to urge that courts accept the challenges involved. It is an entirely different matter for a court to be asked to conduct such a [highly-sensitive and political] hearing successfully. The dangers are obvious." 180 The same is true for the negotiators. These potential formats are easier said than done.

In the context of the implementation of the proposed convention's required, permitted, and prohibited lists, it is also worth noting that there will be some variation in the interpretation of whether a case actually falls within one list versus another. Justice Marshall's choice of words in Kulko v. Superior Court ${ }^{181}$ is all the more relevant: "[F]ew answers will be written in black and white. The grays are dominant and even among them the shades are innumerable." "182 Furthermore, many are correct to highlight the practical reality of underenforcement of human rights judgments in the courts of the world. ${ }^{183}$ Additionally, there are always potential problems with the enforcement of the convention itself, since states often sign on to treaties with the best of intentions, only to breach their terms when push comes to shove. ${ }^{184}$ However, "in an

179. 726 F.2d 774 (D.C. Cir. 1984).

180. Id. at 824 (Robb, J., concurring).

181. 436 U.S. 84 (1978).

182. Id. at 92 (quoting Estin v. Estin, 334 U.S. 541, 545 (1948)).

183. See Marshall, supra note 113, at 617 (reminding us that " $[\mathrm{t}] \mathrm{o}$ this day, Dolly and Joel Filartiga have not received a cent of their judgment against Pena").

184. See Richard B. BILDER, MANAging the RisKs of INTERNATIONAL AgREEMENT 10 (1981) (suggesting that countries often view treaty obligations "more flexibly and in a broader context than traditional legal analysis assumes"). 
interdependent world, most countries will often have little choice but, sooner or later, to do business with each other." ${ }^{185}$

The proposed Hague judgments convention provides a unique opportunity for the members of the Hague Conference to rely upon each other in an effort to overcome some of these very real problems and difficulties. ${ }^{186} \mathrm{~A}$ district court acting with the endorsement of a convention ratified by the United States and by nations from around the world $^{187}$ might feel more comfortable with the prospect of handling political and sensitive cases, removing some of the resistance that hinders the path to enforcement of human rights. Despite some of these aspirations, this Note may provide at least a glimpse into the implications that the proposed convention could have on human rights litigation and assist the negotiators in deciding what course to take.

185. Id. at 11 .

186. The notion of there being strength in numbers is borne out by a parallel observation in the context of the Inter-American human rights system that international tribunals often alleviate the hesitation of individual countries to "point the finger" at human rights violators, allowing the international community as a whole to condemn certain actions. See Pasqualucci, supra note 69 , at $807-08$ (citing the specter of adverse international publicity as a motivation for individual countries to protect against human rights violations).

187. Of course, as perhaps evidenced by the delays in the Hague Conference's consideration of the proposed convention, there is no certainty that the efforts of the negotiators will result in a final convention that is signed and enters into force. In fact, the American Law Institute had originally embarked upon two projects regarding the proposed convention-one drafting implementing legislation if the proposed convention is adopted ("Plan A") and another proposing complementary legislation in the event the proposed convention is not adopted ("Plan B"). See American L. Inst., Project on International Jurisdiction and the Recognition and Enforcement of Foreign Judgments, Council Memorandum No. 2, at 1 (2000) (on file with the Duke Law Journal). However, citing the "extended negotiations at the Hague" and the "prospects for U.S. acceptance of a world-wide Convention continu[ing] to fade," the American Law Institute reporters have recommended putting Plan A on hold, and instead focusing on Plan B. Id. at 2. Additionally, if adopted, there are considerable concerns that the proposed convention could have tremendously negative consequences. Specifically, it might bind judges in state and federal courts throughout the United States to recognize and enforce without question judgments from other countries where the judgments met the basic jurisdictional requirements of the convention even if the judges had serious doubts about the integrity and honesty of the courts issuing the judgments. As noted earlier, however, the proposed convention currently has provisions to deal with these concerns. See supra notes 138-40 and accompanying text. If the negotiators eventually arrive at an acceptable draft of the convention, this Note seeks only to outline its potential impact on human rights litigation. 